\title{
Sectoral variations in market orientation and performance among small service firms in Botswana
}

\author{
Olumide JAIYEOBA \\ Botho University, Gaborone, Botswana \\ Chux Gervase IWU \\ Cape Peninsula University of Technology, South Africa \\ iwuc@cput.ac.za \\ Edward MARANDU \\ University of Botswana, Gaborone, Botswana
}

\begin{abstract}
The quest for the diversification of Botswana's mineral-led economy necessitates an examination of other performing ones such as the Tourism-Transport and Finance-Consulting small service sectors which have been identified as also contributing immensely to its economy. So, this paper investigates variations in market orientation and performance among small service firms in Botswana. In more specific terms, it involves analysis of variations with regard to tourism-transport and finance-consulting firms. Set in Botswana, data were obtained, using a respondent-completed questionnaire from 54 managers in the tourism-transport sector and 121 managers in the financeconsulting sector. Despite the focus of the study on sectoral variations among service firms in Botswana, the study makes major contributions to our understanding of market orientationperformance link. First, the overall level of market orientation varied significantly between the two sectors. Secondly, two of the three components of market orientation, namely intelligence generation and intelligence responsiveness also displayed statistically significant differences between each component and the two sectors. Thirdly, organizational commitment, team spirit and customer satisfaction were significantly different between the two sectors. These findings suggest the need for a sustained and systematic study aimed at finding out the relative importance of market orientation in different sectors. Such a study may be helpful in suggesting differentiated marketing orientation emphases that may help firms optimize their marketing budget. Notwithstanding the several scholarly works on market orientation and firm performance, the value of market orientation in sub-Saharan Africa has only begun to receive attention in Africa. Research evidence is scanty in the case of Botswana.
\end{abstract}

Keywords: market orientation, small service firms, sub-Saharan Africa, Botswana, mineral-led economy.

Please cite the article as follows: Jaiyeoba, O., Iwu, C.G. and Marandu, E. (2018), "Sectoral variations in market orientation and performance among small service firms in Botswana", Management \& Marketing. Challenges for the Knowledge Society, Vol. 13, No 3, pp. 1076-1088, DOI: 10.2478/mmcks-2018-0024.

\section{Introduction}

Notwithstanding the several scholarly works on market orientation and firm performance, its value in sub-Saharan Africa has only begun to receive attention. The relatively few studies (such as the ones by Mahmoud, Blankson, Frimpong and Nwankwo, 2016; Marandu and Themba, 2013; Shehu and Mahmood, 2014) concentrated on understanding its utility 
in facilitating firm growth. In the studies listed above, we note that market orientation was set against different variables namely innovation, organisational culture and employee motivation to shed light on the value of market orientation to a firm. Also, in those studies, testing the hypotheses involved utilizing data in the entire study sample to infer characteristics of the population. Basically, surveying a wide range of respondents within small service firms is consistent with the objective of attaining a representative sample of a diverse range of the population.

In southern Africa, most market orientation studies have focused on South Africa. In fact, in these studies, scholars paid attention to the determinants and barriers of market orientation especially as small and medium service firms are considered to be crucial to the growth of the economy. The assertion espoused above lend credence to Botswana's aspirations in diversifying its economy and empowering its citizens. For instance, the works of Dubihlela (2013), Dubihlela and Dhurup (2014), and Marandu and Themba (2012) not only testify to the need for continuous engagement of issues that pertain to small service firms' performance, but they also amplify the significance of enhancing small service firms' capabilities. The findings of Zikiti (2016) provide parallel support to the need for recognising the criticality of small firms as engines of growth in emerging economies.

Despite its rate of growth, the small service sector in Botswana is still compounded by challenges which include lack of clear understanding of marketing concept or marketing and entrepreneurial strategy that can enable them to understand customers better in order to realize superior business performance (CEDA, 2010; Local Enterprise Authority (LEA), 2009). Therefore, considering the high proportion of small firms, its volatility and potential importance to the Botswana economy, further clarification of determinants of success in the context of market orientation behaviour should make a useful and practical contribution to business practice.

According to Botswana Institute of Development and Policy Analysis (BIDPA, 2008) and Citizen Entrepreneurial Development Agency Annual Report (CEDA, 2012), the services sector is the fastest growing sector. CEDA (2012) also states that the services sector constitutes $45 \%$ of the projects with respect to financial support in terms of sectoral distribution. Interestingly, in a mineral-led economy, the services sector has emerged as the most dominant in the small firms sector in Botswana. The services sector is largely composed of tourism, transport, financial and consulting firms. BIDPA (2008) and CEDA (2012) are in agreement that the knowledge and ingenuity of entrepreneurs are driving this transformative process as Botswana seeks to transform its economy into a knowledge based society. This is critical especially considering that $60 \%$ of the population is made up of young people who are possibly yearning to contribute significantly to the growth of the economy.

Botswana is a mineral-led economy and as such diversifying the economy is a legitimate concern. This is in line with Vision 2036 mandate of a transformed economy. Reliance on natural resources has its demerits. For one, independence on mineral equates to what Wright and Czelusta (2003) refer to as the constant depletion of a fixed natural endowment. Moreover, resource-rich countries, in the long run, often become economically bereft than resource-deprived ones (Zikiti, 2016). In keeping with the agenda of moving significantly away from its mineral-led economy, a panel of experts at the 2015 Business Innovation and Growth Conference which was held in Botswana called for intensified interest in market orientation studies. In fact, they suggested that instead of holistically 
looking at the antecedents and consequences of market orientation for small service firms as a one size fits all approach, researchers should rather examine the antecedents and consequences of small service sectors such as tourism, transport, and financial consulting firms in order to explicate to what extent the service sectors differ with respect to antecedents of market orientation, its behaviour and consequences.

That was a major factor that prompted this study but more importantly our collective insight that, despite the usefulness of data that captures market orientation and performance statistics for a diversity of firms in an aggregate fashion, analysis of data according to sub-groups may reveal important differences that may be concealed in global averages. This insight was also derived from the discussions at the Business Innovation and Growth Conference, which seemed to suggest that the approach of combining different sectors introduces problems associated with sample heterogeneity which undermines the reliability of research outcomes. This paper therefore addresses this concern by focusing on differences between sectors of the sample firms. The study seeks to unravel the extent to which antecedents and consequences of market orientation behaviour differ between tourism-transport service sector and finance-consulting services sector in Botswana. Given the foregoing, we pursued answers to the following questions: (1) Are there significant differences between antecedents of market orientation behaviour with regard to small service sectors in Botswana, and (2) Are there significant differences in economic and noneconomic performance metrics in small service sectors in Botswana?

This study was undertaken due to the peculiar nature of services in the context of intangibility metrics. Small service firms in Botswana have shown evidence of growth capabilities which call for ways to enhance their growth. Therefore, this study sheds light on the extent to which antecedents and consequences of market orientation behaviour inform strategic decision making in the sampled service sectors. After all, contemporary market orientation literature offers a rich, but fragmented picture of what MO is and how it can be improved.

Research objectives of the paper are to determine if the level of market orientation and its antecedents vary with the sector of the sampled firms in Botswana; and to establish if economic and non-economic performance metrics vary with the sector of the sampled firms in Botswana.

The structure of the rest of the paper is as follows: The next section is the literature review which discusses the concept of market orientation in relation to small firm's performance. Thereafter, the research methods are discussed. The results follow with concluding remarks that suggest future research direction as well as implications for theory and practice.

\section{Literature review}

\section{Antecedents of market orientation behaviour}

Market orientation has received much attention in the marketing literature. For instance Aziz and Yassin (2010), Tsiotsou and Vlachopoulou (2011) and Mahmoud, Blankson, Frimpong and Nwankwo, (2016) describe market orientation as those organisation's activities that manifest the adoption of marketing concept. Raaij and Stoelhorst (2008) as well as Aydin and Mtetwa (2015) extensively studied antecedents of market orientation 
from an implementation perspective so as to understand how they provide clues about developing a firm's market orientation.

It is widely assumed that managers can improve market orientation by emphasizing market-oriented attitudes and behaviours (Kirca, Jayachandran and Bearden, 2005; Dubhilela, 2013). In fact, Zebal and Goodwin (2011) are of the view that market-oriented attitudes and behaviours are products of focused employee development programmes. Raaij and Stoelhorst (2008) contend that internal and external antecedents stimulate and enable a firm's adoption of market orientation concept.

Antecedents of market orientation behaviour are usually broken down into two namely internal and external antecedents. Internal antecedents include organisational characteristics such as centralisation, formalisation, political behaviour, interdepartmental conflict and connectedness as market based reward systems (Vieira, 2010). The external antecedents include market turbulence, competition, technological orientation (Zebal and Goodwin, 2011) and general economy (Vieira, 2010), all of which provide critical levers for implementing market orientation in a firm.

Cardogan (2012) thus noted that while the body of research on the consequences of market orientation is large, relatively little research most especially among service sectors has (1) investigated the antecedents, and consequences of market orientation in Botswana and (2) identified the principal types of management behaviour which affect the extent to which a firm can successfully achieve market orientation. Shehu and Mahmood (2014) and Zebal and Goodwin (2011) thus insist that for small firms to compete, they need marketing metrics that are built on informality, flexibility and personalised customer relationships in product and service preferences for exploring market opportunities.

\section{Market orientation behaviour and small firms}

The market orientation concept has its origin in a management philosophy known as the marketing concept (Raaij and Stoelhorst, 2008). Literature describes market orientation as a set of behaviours and processes (Kohli and Jaworski, 1990 cited in Keskin, 2006) or an aspect of culture (Narver and Slater, 1990 cited in Keskin, 2006) to create superior customer value. For instance, Kohli and Jaworski (1990) adopt a process approach and use the term market orientation to mean the implementation of a marketing concept via market intelligence generation, intelligence dissemination and responsiveness. By using a cultural framework, Slater and Narver (1995) extended the boundary of market orientation concept by incorporating the development of information about competitors and interfunctional collaboration.

The generation of market intelligence relies not only on customer surveys but also on a host of complimentary mechanisms as argued by Oniku (2009). These complimentary mechanisms relate to what Kibera and Njeru (2014) refer to as careful analysis and interpretation of customer needs and preferences. With regard to intelligence dissemination, Awwad and Agti (2014) refer to it as information developed at the intelligence generation stage which must be shared with other functional units of the business. Akomea and Yeboah (2011) describe responsiveness as the actions taken after market intelligence is generated and disseminated such as market planning to market mix tactics.

Dubhilela and Dhurup (2014) thus posit that market orientation is a cognitive, behavioural and cultural aspect of a firm's marketing concept that puts the customer at the 
centre of the organisation and its development. Bodlaj (2010) thus argues that the various definitions of market orientation overlap considerably and can be integrated into a broader aggregate definition. However, back in 2006, Rojas-Mendez, Kara and Spillan (2006) argued that MARKOR's scale was more reliable and valid to measure market orientation in varied contexts.

The marketing literature indicates that the adoption of the marketing concept is a foundation for successful performance of firms (Nwokah, 2008; Dubhilela and Dhurup, 2014). Zebal and Goodwin (2011) thus contend that market orientation is a business orientation that puts the customer at the centre of the firms thinking about strategy and operation. As stated earlier, the research community largely shares the view that small firms are valuable to the economy as they play a major role in job creation (Sanjaya, Vasudevan and Gaur, 2011; Kibera and Njeru, 2014). This study thus sheds light on the role of market orientation most especially among service sectors in explaining business performance using Botswana as a study context.

\section{Market orientation behaviour and performance}

The implementation of the marketing concept has been interpreted as a stage of development and posited to lead to greater customer satisfaction and organisational commitment of employees (Marandu and Themba, 2012). Research has thus shown that a firm's degree of market orientation has a positive effect on business performance (Blackburn, Hart and Wainwright, 2013; Aydin and Mtetwa, 2016). Dauda (2010) thus argues that empirical support exists for positive impacts of market orientation on customer perceived quality, customer satisfaction and loyalty as well as employee satisfaction. Additionally, Sanjaya, Vasudevan and Gaur (2011) and Aydin and Mtetwa (2016) also contend that market orientation provides a firm with market sensing and customer linking capabilities that lead to superior organisational performance. Marandu and Themba (2012) are of the view that market orientation provides psychological and social benefits to employees and enhances esprit de corps and team work. Consequently, O'Dwyer, Gilmore and Carson (2011) and Aydin and Mtetwa (2016) postulate that companies that offer superior customer value are expected to enjoy superior long term competitive advantage and superior profitability. Nonetheless, McNaughton, Osborne and Imrie (2002) and Zebal and Goodwin (2011) are of the view that the final effect of market orientation on firm's performance still remains ambiguous, which is even more critical in the service sectors, given the inherent intangibility, ephemeral nature and other peculiarities of services which affect the relationship. Hence the need for this study among service sectors in Botswana.

\section{Methodology}

The study is quantitative and descriptive in nature. Data were collected from owner/managers of small service firm's subsectors of Tourism-Transport and FinanceConsulting. A total of 175 owner/managers from Tourism-Transport Finance-Consulting sectors in Botswana participated in this study. Reliability and validity tests were conducted to explicate the psychometric nomenclature of the constructs in this study. Gaborone, Francistown, Selebi-Phikwe and Maun were covered in this study for representativeness and generalizability as they constitute the major economic hubs of Botswana. The instrument used in collecting data composed mainly of close-ended items to ensure a 
higher response rate from the subjects, given the peculiar nature of owner-managers of small service firms. The research instrument for this study was adapted from Kohli and Jaworski's (1993) MARKOR scale. The standardised market orientation scale items were contextualised to Botswana's settings in the most appropriate, yet simplest business language, with a view to getting the most useful response from the participants.

Self-administered questionnaires were used to collect the data. The questionnaires commenced with a preamble and screening questions to ensure that prospective respondents were indeed part of the target population of the study. Initially, 370 questionnaires were distributed but only 175 were deemed usable which represents $47 \%$ response rate. The sample was thus selected using the non-probability sampling technique. Snowball sampling technique was used due to non-availability of a sampling frame in this study context (CEDA Annual Report, 2012).

The scale items were tested for reliability and validity in order to explicate the factor structure of the research instrument and were found to fulfil the minimum threshold as postulated by Isabel and Garcia (2015). The internal consistency was measured using Cronbach Alpha while the factor structure was measured using Kaiser Meyer Olkin (KMO) of sampling adequacy and Battlett's test of sphericity. Descriptive statistics were calculated using SPSS Version 21 to gain insight into the demographic profile of respondents and the items measuring the constructs of the study. The Levene's test for equality of variances and t-test for equality of means were used to establish differences, if any, among sampled service sectors.

\section{Findings}

Data analysis was conducted with regard to the Tourism-Transport and Finance-Consulting sectors. It involved the use of the SPSS Version 21 package to compute descriptive statistics and mean differences between the two sectors. The analysis involved three phases: first the mean scores of the aggregate and individual dimensions in the market orientation construct were computed for the two sectors and the differences were tested for statistical significance. Second, the same type of analysis was carried out for the antecedents of market orientation. Finally the same type of analysis was carried out for the consequences of market orientation. To test the mean differences between the sectors, the t-test for two independent samples was utilized with significance set at the conventional 5 percent level of probability, for one-tailed tests. The findings are presented in consonance with the three phases of the analysis as follows:

\section{Market orientation by sector}

The first level of analysis involved testing the difference in market orientation with regard to the two sectors. Table 1 presents the mean level of the overall or aggregate market orientation for the sample sectors as well as the mean level of the constituent dimensions of the market orientation construct. In addition the mean differences between the two sectors are shown as well as their statistical significance levels. The analysis produces three interesting revelations:

First, the findings demonstrate that, the mean scores of the Tourism-Transport sector are, without exception, consistently higher than those in the Finance-Consulting sector. 
Second, the $t$ significance level indicates that the mean difference of 0.41 between the Tourism-Transport sector (higher) and the Finance-Consulting sector was statistically significant, taking marketing orientation as an aggregate (overall).

Third, the $t$ significance levels tell that when taking each of the three dimensions of market orientation, one at a time, the three dimensions of market orientation differed significantly between the Tourism-Transport sector and the Finance-Consulting sector groups, with regard to Intelligence Generation and Intelligence Responsiveness. Intelligence Dissemination did not display statistically significant mean difference.

Table 1. Level of Market Orientation by Sector

\begin{tabular}{|c|c|c|c|c|c|c|c|c|}
\hline & \multicolumn{4}{|c|}{ Sectors } & & & & \\
\hline & \multicolumn{2}{|c|}{$\begin{array}{l}\text { Tourism- } \\
\text { Transport }\end{array}$} & \multicolumn{2}{|c|}{$\begin{array}{l}\text { Finance- } \\
\text { Consulting }\end{array}$} & & & & \\
\hline & Mean & SD & Mean & SD & $\begin{array}{l}\text { Mean } \\
\text { Difference }\end{array}$ & $\mathbf{t}$ & df & Probability \\
\hline $\begin{array}{l}\text { Overall market } \\
\text { orientation }\end{array}$ & 3.61 & .564 & 3.20 & 0.824 & 0.41 & $\begin{array}{l}3.38 \\
2\end{array}$ & 184 & 0.0005 (Sig) \\
\hline $\begin{array}{l}\text { Intelligence } \\
\text { generation }\end{array}$ & 3.69 & .507 & 3.36 & 0.707 & 0.33 & $\begin{array}{l}3.40 \\
0\end{array}$ & $\begin{array}{l}138.66 \\
2\end{array}$ & 0.0005 (Sig) \\
\hline $\begin{array}{l}\text { Intelligence } \\
\text { dissemination }\end{array}$ & 3.54 & .605 & 3.44 & 0.723 & 0.10 & $\begin{array}{l}0.87 \\
4\end{array}$ & 184 & $\begin{array}{l}0.1915 \text { (Not } \\
\text { sig) }\end{array}$ \\
\hline $\begin{array}{l}\text { Intelligence } \\
\text { responsiveness }\end{array}$ & 3.19 & .479 & 2.86 & 0.465 & 0.33 & $\begin{array}{l}4.34 \\
7 \\
\end{array}$ & 4.347 & 0.0000 (Sig) \\
\hline
\end{tabular}

Source: Authors' own research.

\section{Antecedents of market orientation by sector}

The second level of analysis involved testing the level of antecedents of market orientation in the two sectors. Table 2 displays a total of 14 antecedent factors consisting of 10 internal antecedents and 4 external antecedents, sorted in order of statistical significance of their mean difference between Tourism-Transport and Finance-Consulting sectors. Two main points emerge from the analysis:

First, 7 of the 14 antecedents (ranging from "Formalization" to "Technology Turbulence") demonstrated differences between the two sectors that were statistically significant.

Second, it is of interest to note that, of the seven antecedents that showed statistically significant differences, the mean scores of the Tourism-Transport sector were, again, consistently higher than those in the Finance-Consulting sector. 
Table 2. Antecedents of Market Orientation by Sector

\begin{tabular}{|c|c|c|c|c|c|c|c|}
\hline & \multicolumn{2}{|c|}{ Sectors } & & & & \\
\hline & & \multirow{2}{*}{$\begin{array}{c}\begin{array}{c}\text { Tourism- } \\
\text { Transport }\end{array} \\
\text { Mean } \\
\end{array}$} & \multirow{2}{*}{\begin{tabular}{|c|}
$\begin{array}{l}\text { Finance- } \\
\text { Consulting }\end{array}$ \\
Mean \\
\end{tabular}} & & & & \\
\hline & $\begin{array}{l}\text { Type of } \\
\text { Antecedent }\end{array}$ & & & $\begin{array}{c}\text { Mean } \\
\text { Difference }\end{array}$ & $t$ & df & Probability \\
\hline 1. Formalisation & INT ANT & 3.74 & 3.05 & 0.69 & $\begin{array}{c}6.47 \\
4\end{array}$ & $\begin{array}{c}157.29 \\
3\end{array}$ & 0.0000 (sig) \\
\hline $\begin{array}{ll}\text { 2. } & \text { Market based } \\
& \text { reward system }\end{array}$ & INT ANT & 4.02 & 3.65 & 0.37 & $\begin{array}{c}3.45 \\
0\end{array}$ & $\begin{array}{c}118.26 \\
0\end{array}$ & 0.0005 (sig) \\
\hline $\begin{array}{l}\text { 3. Interdepartment } \\
\text { al conflict }\end{array}$ & INT ANT & 4.02 & 3.65 & 0.37 & $\begin{array}{c}3.45 \\
0\end{array}$ & $\begin{array}{c}118.26 \\
0\end{array}$ & 0.0005 (sig) \\
\hline $\begin{array}{ll}\text { 4. } & \text { Market } \\
\text { turbulence }\end{array}$ & EXT ANT & 3.76 & 3.42 & 0.34 & $\begin{array}{c}2.84 \\
9\end{array}$ & 184 & 0.0025 (sig) \\
\hline 5. Competition & EXT ANT & 3.48 & 3.08 & 0.40 & $\begin{array}{c}2.77 \\
5\end{array}$ & 184 & 0.0030 (sig) \\
\hline $\begin{array}{ll}\text { 6. } & \text { Management } \\
\text { training }\end{array}$ & INT ANT & 3.28 & 3.08 & 0.20 & $\begin{array}{c}2.30 \\
4\end{array}$ & 87.232 & 0.0120 (sig) \\
\hline $\begin{array}{ll}\text { 7. } & \text { Technology } \\
\text { turbulence }\end{array}$ & EXT ANT & 3.63 & 3.38 & 0.25 & $\begin{array}{c}2.27 \\
3\end{array}$ & $\begin{array}{c}137.76 \\
1\end{array}$ & 0.0125 (sig) \\
\hline $\begin{array}{ll}\text { 8. } & \text { Formal } \\
\text { marketing } \\
\text { education }\end{array}$ & INT ANT & 3.19 & 3.31 & -0.12 & $\begin{array}{c}- \\
1.50 \\
8 \\
\end{array}$ & $\begin{array}{c}147.64 \\
7 \\
\end{array}$ & $\begin{array}{l}0.0670 \text { (not } \\
\text { sig) }\end{array}$ \\
\hline 9. Risk aversion & INT ANT & 3.72 & 3.57 & 0.15 & $\begin{array}{c}1.29 \\
7\end{array}$ & $\begin{array}{c}151.57 \\
8\end{array}$ & $\begin{array}{l}0.0980 \text { (not } \\
\text { sig) }\end{array}$ \\
\hline $\begin{array}{l}\text { 10. Top management } \\
\text { emphasis }\end{array}$ & INT ANT & 4.07 & 4.18 & -0.11 & $\begin{array}{c}- \\
1.00 \\
9\end{array}$ & 173 & $\begin{array}{l}0.1575 \text { (Not } \\
\text { sig) }\end{array}$ \\
\hline 11. General economy & EXT ANT & 3.46 & 3.54 & -0.08 & $\begin{array}{c}- \\
0.80 \\
1\end{array}$ & 173 & $\begin{array}{l}0.2120 \text { (not } \\
\text { sig) }\end{array}$ \\
\hline $\begin{array}{l}\text { 12. Interdepartment } \\
\text { al connectedness }\end{array}$ & INT ANT & 4.15 & 4.07 & 0.08 & $\begin{array}{c}0.79 \\
6\end{array}$ & 184 & $\begin{array}{l}0.2135 \text { (not } \\
\text { sig) }\end{array}$ \\
\hline 13. Centralisation & INT ANT & 3.13 & 3.05 & 0.08 & $\begin{array}{c}0.53 \\
6 \\
\end{array}$ & 184 & $\begin{array}{l}0.2965 \text { (not } \\
\text { sig) }\end{array}$ \\
\hline $\begin{array}{l}\text { 14. Political } \\
\text { behaviour }\end{array}$ & INT ANT & 2.79 & 2.81 & -0.02 & $\begin{array}{c}- \\
0.17 \\
2\end{array}$ & $\begin{array}{c}141.31 \\
3 \\
\end{array}$ & $\begin{array}{l}0.4320 \text { (not } \\
\text { sig) }\end{array}$ \\
\hline
\end{tabular}

Source: Authors' own research.

\section{Consequences of market orientation by sector}

The third level of analysis involved testing the mean differences in the consequences of market orientation in the two sectors. Table 3 displays five measures of consequences of market orientation, sorted out in order of statistical significance of their mean difference between the two sectors. Two main findings arise from the study:

First, three of the five consequences of market orientation (Organizational commitment, Esprit de corps, and Customer satisfaction) displayed statistically significant differences between the two sectors. 
Second, it is of interest to note that of the three consequences of market orientation that displayed statistically significant differences, the mean scores of the TourismTransport sector were, once again, higher than those in the Finance-Consulting sector.

Table 3. Consequences of Market Orientation by Sector

\begin{tabular}{|c|c|c|c|c|c|c|}
\hline & \multicolumn{2}{|c|}{ Sectors } & & & & \\
\hline & $\begin{array}{l}\text { Tourism- } \\
\text { Transport }\end{array}$ & $\begin{array}{l}\text { Finance- } \\
\text { Consulting }\end{array}$ & & & & \\
\hline & Mean & Mean & $\begin{array}{c}\text { Mean } \\
\text { Difference }\end{array}$ & $\mathrm{t}$ & $\mathrm{df}$ & Probability \\
\hline $\begin{array}{l}\text { 1. } \begin{array}{l}\text { Organizational } \\
\text { commitment }\end{array} \\
\end{array}$ & 3.24 & 2.89 & 0.35 & 4.158 & 125.143 & $0.0000(\mathrm{Sig})$ \\
\hline 2. $\quad$ Esprit de corps & 3.74 & 3.30 & 0.44 & 3.824 & 142.812 & 0.0000 (Sig) \\
\hline $\begin{array}{ll}\text { 3. } & \text { Customer } \\
& \text { satisfaction }\end{array}$ & 3.93 & 3.65 & 0.28 & 3.286 & 154.443 & 0.0005 (Sig) \\
\hline $\begin{array}{ll}\text { 4. } & \begin{array}{l}\text { Business } \\
\text { performance }\end{array} \\
\end{array}$ & 3.83 & 3.82 & 0.01 & 0.109 & 151.084 & 0.4565 (Not Sig) \\
\hline 5. Repeat customers & 3.22 & 3.31 & -0.09 & -1.001 & 173 & 0.1590 (Not Sig) \\
\hline
\end{tabular}

\section{Conclusion, recommendation, limitations, implications and future research direction}

A firm's strategic orientation reflects the strategic directions it implements so as to create long term efficiencies that enable performance. Much of this is achieved through a firm's concerted effort at market orientation. Broadly speaking, market orientation refers to a firm's efforts to ascertain and meet the needs and desires of its customers by making use of its product mix. Basically, market orientation translates into capabilities that help firms to learn and adapt by investigating the importance of customer retention orientation in the development of higher-order marketing and adaptive capabilities. That said, it is noteworthy that besides having sufficient considerations for its competitors and being able through coordinated effort of different functions within the firm to provide value which exceeds customer expectations, the firms must develop long-term relations with customers.

The quest for the diversification of Botswana's mineral-led economy necessitates an examination of other performing ones such as the Tourism-Transport and FinanceConsulting small service sectors which have been identified as also contributing immensely to its economy. The small service sector in Botswana is looked upon as a valuable contributor to the economy thereby requiring extra capabilities which can be harnessed through scholarly empirical research. Therefore, to enable the sectors understand customers better so as to offer them superior service, it became expedient to carry out a study such as this.

We thus set out to find answers to very important research questions namely (1).are there significant differences between market orientation and its antecedents with regard to service sectors in Botswana? And (2) are there significant differences in economic and noneconomic performance metrics in service sectors of Botswana? 
The reason behind these inquiries was to determine significant differences of market orientation behaviour among small service sector firms in Botswana to deepen an understanding of how these firms can develop higher-order marketing and adaptive capabilities that can stand them in good stead over competitors thereby enlarging market share and differentiation. After all, marketing literature confirms that market orientation has a significant impact on a firm's performance. This study provides empirical support for the long held proposition that internal and external marketing concepts are related and that organisations especially small service firms, should balance their external focus with some attention to customers and employees for improved business performance to be achieved. The role of antecedents such as interdepartmental connectedness, centralisation, interdepartmental conflict, top management emphasis, competition, market turbulence and overall market orientation as well as consequences of MO behaviour were analysed in this study to provide additional insight into the differences that exist among the antecedents and consequences of market orientation based on small service firms sectors with respect to Transport-Tourism and Finance-Consulting services in Botswana. The results indicate an urgent need for the implementation of the marketing concept as it represents an indispensable platform for empowerment in Botswana especially considering the drive to refocus the mineral-led economy to sustainable services sectors that have the capacity to employ and create entrepreneurial opportunities for the future.

In the form of a summary, we reiterate that overall, market orientation has been found to have a significant and positive effect on business performance, team spirit and customer satisfaction. This finding resonates with extant literature (Marandu and Themba, 2012; Zebal and Goodwin, 2011). However, while organisational commitment, esprit de corps, customer satisfaction indicate significant differences, business performance and repeat customer did not indicate significant differences among the sampled sectors in Botswana. Market turbulence, formalisation, market based reward system and interdepartmental conflict show significant differences, while top management emphasis, risk aversion, formal marketing education, centralisation, political behaviour and interdepartmental connectedness did not indicate significant differences. For market orientation metrics, while intelligence generation, intelligence responsiveness and market orientation behaviour indicate significant differences, the intelligence dissemination metric did not indicate any significant differences among sampled small firm sectors in Botswana. Additionally, competitive intensity, market turbulence and technological turbulence demonstrate significant differences, while general economy indicates no significant differences in Botswana.

This study contributes to extant literature by examining the effect of antecedents and market orientation behaviour on the performance of small service firms in different service sectors. As we know and drawing from the work of Aziz and Yassin (2010), due to inseparability, heterogeneity and perishability, small service firms require the concept of market orientation more than large firms due to their size, nature of offerings, operational constraints, as well as the orientation that services are consumed directly. The results thus help advance the nexus between contingency theory and market orientation with respect to service sectors. Additionally, the implication of the empirical results for managers is that they should appraise a combination of internal and external antecedents that are critical to market orientation behaviour. Hence, the one size fits all approach hitherto adopted irrespective of service sectors should be revised by managers, policy makers and other 
institutional frameworks in Botswana. Our findings also suggest the need for a systematic study aimed at finding out the relative importance of market orientation in different sectors. Such a study may be helpful in suggesting differentiated marketing orientation emphases that may help firms optimize their marketing budget. The lack of objective financial performance data limits the paper as far as business performance effects are considered. Comparative studies in other subsectors or national settings and different cultural context may explicate different results. In addition, conceptual or qualitative empirical studies are needed in order to obtain a clearer understanding of the effectiveness of the antecedents and consequences of market orientation in the context of service firms. This study thus presents the small service perspective of sectors in Botswana and essentially adds to the interface of market orientation and outcomes in Botswana.

\section{References}

Akomea, S.Y and Yeboah, J.K.G (2011), "Marketing orientation and firm performance in Ghana's Pharmaceutical Industry”, Journal of Science and Technology, Vol 31, No. 2, pp. 109-119.

Awwad, M.S and Agti, D.A.M (2011), "The impact of internal marketing on commercial Bank's market orientation", International Journal of Bank Marketing, Vol. 29, No. 4, pp. 308-332.

Aydin, K and Mtetwa T (2016), "Impact of marketing effectiveness and capabilities and export market orientation on export performance: evidence from Turkey", European Business Review Vol. 28m No. 5, pp. 532-559.

Aziz, N.A and Yassin, N.M. (2010), "How will market orientation and external environment influence the performance among SMEs in the Agro-Food sector in Malaysia", Journal of international Business Research, Vol.3, No. 3, pp.154-164.

BIDPA, (2008) Botswana Institute of Development and Policy Analysis Profile.

Bodlaj, M (2010), "The impact of a responsive and proactive market orientation on innovation and business performance", Economic and Business Review, Vol. 12, No. 4 , pp. 241-261.

Cadogan, J.W. (2012), "International marketing strategic orientations and business success: reflections on the path ahead", International Marketing Review, Vol. 29, Issue 4, pp. 340-348.

CEDA, (2010), Annual Report Publications.

CEDA, (2012), Annual Report Publications.

Dauda, A. Y. (2010), “Employee's market orientation and business performance in Nigeria: analysis of small business enterprises in Lagos state", International Journal of Marketing Studies, Vol. 2, No. 2, pp. 134-143.

Dubihlela, J. (2013), "Determinants of market orientation adoption among small and medium enterprises (SMEs) in South Africa", Mediterranean Journal of Social Sciences, Vol.4, No.6, pp. 55-65.

Dubihlela, J. and Dhurup, M. (2014), "Modelling the effects of market orientation enablers on business performance among SMEs in a developing country", Mediterranean Journal of Social Sciences, Vol.5, No. 16, pp. 33-41.

Isabel A.P. and Garcia, J. (2015), "Market orientation and business results among small service firms", Academia Revista de Adiminstration, Vol. 28, Issue 1, pp. 135-166. 
Jaiyeoba, 0.0, Marandu, E, and Kealesitse, B., "Proclivity of environmental uncertainty and market orientation behaviours among Botswana's small service firms", Journal of Global Business and Technology, Vol. 11 No. 1 pp. 13-23.

Kibera, F.N and Njeru,W.G (2014), "The perceived effects of the three components of market orientation on the performance of tour firms in Kenya", European Scientific Journal, Vol. 10, No. 25, pp. 266-285.

Kirca, A. H., Jayachandran, S. and Bearden, W. O. (2005), "Market orientation: a metaanalytic review and assessment of its antecedents and impact on performance", Journal of Marketing, Vol. 69, No. 2, pp. 24-41.

Kohli, A.K. and Jaworski, B.J. (1990), "Market orientation: the construct, research propositions, and managerial implications", Journal of Marketing, Vol. 54, No. 2, pp. 1-18.

Mahmoud, A.M, Blankson, C, Frimpong, N.O and Nwankwo, S (2016), "Market orientation, learning orientation and business performance: the mediating role of innovation", International Journal of Bank Marketing, Vol. 34, No.5, pp. 623-648.

Marandu E.E. and Themba, G. (2012), "The effects of market orientation on employees: a study of retail organisations in Botswana", International Business Research, Vol. 6, No. 1, pp.130-136.

Narver, J. C. and Slater, S. F. (1990), "The effect of a market orientation on business profitability",_Journal of Marketing, Vol. 54, No. 4, pp. 20-35.

Nwokah, N.G. (2008), "Strategic market orientation and business performance: the study of food and beverages organisations in Nigeria", European Journal of Marketing, Vol. 42, No. 3/4, pp. 279-286.

O'Dwyer, M., A. Gilmore A and D. Carson (2011), "Strategic alliances as an element of innovative marketing in SMEs", Journal of Strategic Marketing, Vol. 19, No. 1, pp.91104.

Oniku A.C (2009), "Market Orientation: SMEs Performance under Government Economic and Market Reforms in Nigeria", Conference of the International Journal of Arts and Sciences, Vol. 1, No. 20, pp. 186-205.

Raaij, V. M. E. and Stoelhorst, W. J. (2008) "The implementation of market orientation - a review and integration of contributions to date", European Journal of Marketing, Vol. 42, No. 11/12, pp. 1265-1293. Available from www.emeraldinsight.com (Accessed on $14^{\text {th }}$ November 2010 ).

Rojas-Mendez, I. J., Kara, A. and Spillan, E. J. (2006), "Market Orientation in the Chilean Small Business Context: An Empirical Study", Journal of Global Marketing, Vol. 19, No. 3/4, pp. 93-132. Available from http://igm.haworthpress.com (Accessed on $1^{\text {st }}$ October 2010).

Sanjaya, S.G., Vasudevan, H., and Ajai, S.G (2011), "Market orientation and manufacturing performance of Indian SMEs: Moderating role of firm resources and environmental factors", European Journal of Marketing, Vol. 45, Issue 7, pp. 1172-1193.

Schiffman, Leon G, \& Kanuk, L.L. (1994), Consumer Behavior. 5th Edition, Prentice-Hall: London.

Shehu A.M. and Mahmood R. (2014), "The Relationship between Market Orientation and Business Performance of Nigerian SMEs: The Role of Organisational Culture", International Journal of Business and Social Science, Vol. 5, No. 9, pp. 159-167. 
Tsiotsou, R. H., and Vlachopoulou, M. (2011), "Understanding the effects of market orientation and e-marketing on service performance", Marketing Intelligence and Planning, Vol. 29, No. 2, pp. 141-155.

Wright, G, and Czelusta, J. (2003), "Mineral resources and economic development", In: Conference on Sector Reform in Latin America, Stanford Center for International Development, Nov. 2003, pp. 13-15.

Zikiti, B. (2016), "How can Zimbabwe leverage its mineral resources for economic recovery and sustainable growth", Unpublished Master of Commerce dissertation, University of the Witwatersrand, South Africa. 